Molecules 2005, 10, 1340-1350

molecules

ISSN 1420-3049

http://www.mdpi.org

\title{
Formation of New Alkynyl(phenyl)iodonium Salts and Their Use in the Synthesis of Phenylsulfonyl Indenes and Acetylenes
}

\author{
Alexandros E. Koumbis *, Christos M. Kyzas, Antri Savva and Anastasios Varvoglis * \\ Department of Chemistry, Aristotle University of Thessaloniki, Thessaloniki 54124, Greece. Tel.: \\ (+30)-2310-997839, Fax: (+30)-2310-997679.
}

* Authors to whom correspondence should be addressed; e-mails: akoumbis@chem.auth.gr; anvar@chem.auth.gr

Received: 31 March 2005 / Accepted: 27 July 2005 / Published: 31 October 2005

\begin{abstract}
The preparation of phenylsulfonyl indene derivatives and phenylsulfonylacetylenes from readily available alkynyl(phenyl)iodonium tetrafluoroborates and triflates was investigated using phenylsulfinate as nucleophile.
\end{abstract}

Keywords: Indene, alkynyl(phenyl)iodonium salt, sulfinate, carbene, rearrangement.

\section{Introduction}

Among the various known hypervalent iodine species alkynyliodonium salts represent an interesting class of compounds regarding their applications in organic synthesis [1-9]. Their major subgroup comprises a multitude of stable alkynyl(aryl)iodonium salts (1, Scheme 1) [9]. Since the first preparation of a labile alkynyl(aryl)iodonium salt [10] and the isolation of the first stable one [11] their reactivity patterns have been thoroughly studied. It is nowadays well established that $\mathbf{1}$ are, among other things, excellent partners for Michael-type conjugate additions as well as dienophiles in DielsAlder reactions and dipolarophiles in 1,3-dipolar cycloadditions [9]. The great tendency of $\mathbf{1}$ to react with nucleophiles via conjugate addition is a result of the highly electrophilic nature of the $\beta$ acetylenic carbon. The subsequent fate of the initially formed iodonium ylide 2 depends on the reaction conditions (Scheme 1). Thus, reaction with a proton donor will yield an alkenyliodonium ion 3, whereas carbene 4 is formed via iodobenzene elimination. This carbene then either inserts intramolecularly into any suitable bond available (mainly a $\mathrm{C}-\mathrm{H}$ bond from either $\mathrm{R}$ or $\mathrm{Nu}$ ) to produce five-membered ring systems 5 and $\mathbf{6}$ or rearranges to give a new alkyne 7. By employing C-, O-, N- 
and S-nucleophiles [6-9,12] several substituted cyclopentenes [13], cyclopentenones [14] or heterocyclic derivatives such as pyrroles [15], indoles [16], thiazoles [17] and benzofurans [12,18] have been obtained. Sulfinate anions in particular were used as nucleophiles in the construction of cyclopentenes [13,19-20] and cyclopentenones [14]. Herein we wish to report our latest results concerning the additions of benzenesulfinate to alkynyl(phenyl)iodonium salts in order to obtain indene and (or) alkyne derivatives.

\section{Scheme 1.}

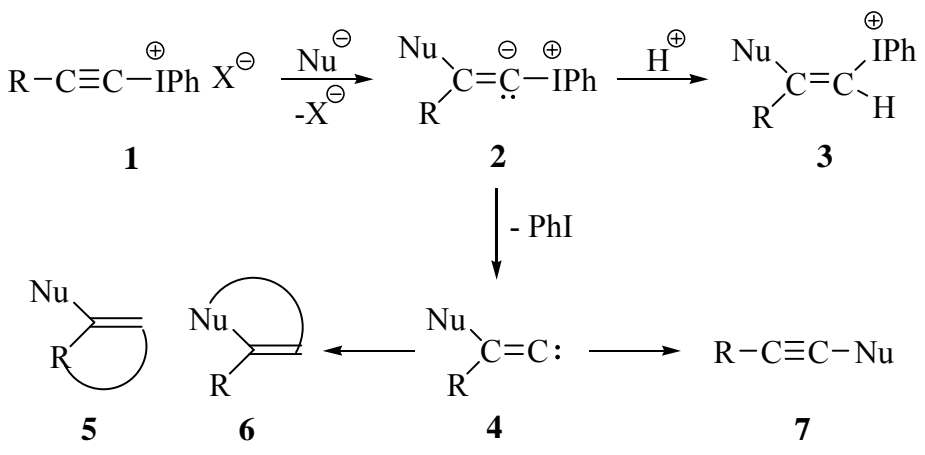

\section{Results and Discussion}

The required alkynyl(phenyl)iodonium salts, 11 and 13, were prepared from the corresponding $o$-substituted phenyliodides 8a-c [21-22] (Scheme 2). These were first converted to arylalkynes 9 in very good yields through a Sonogashira reaction [23-24]. Some of the corresponding desilylated products $\mathbf{1 0}$ were also obtained in these reactions. Arylalkynes $\mathbf{9}$ were then treated first with iodosylbenzene in the presence of $\mathrm{BF}_{3} \cdot \mathrm{OEt}_{2}$ [25] and subsequently with aqueous $\mathrm{NaBF}_{4}$ [26-27] to produce tetrafluoroborates 11. The Zefirov reagent 12 [28] was also used to prepare the triflate analogues 13 directly from the same intermediates 9 [29-30].

Scheme 2.

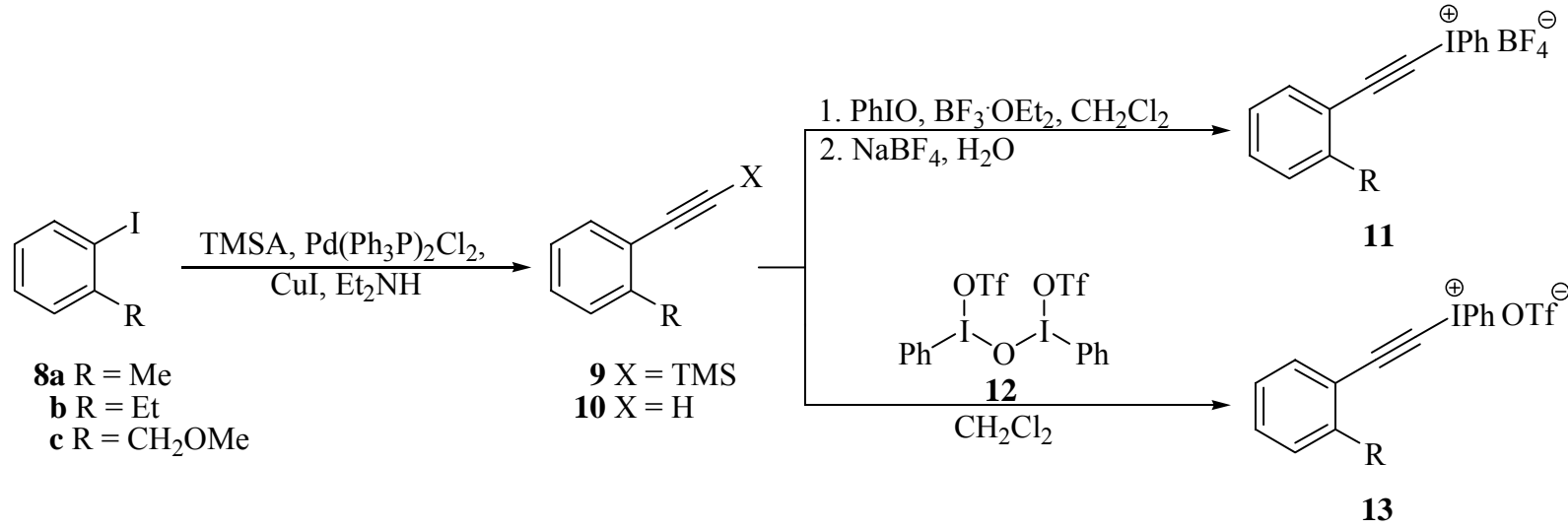

1-Bromonaphthalene (14) was similarly used to prepare the corresponding iodonium salts (Scheme 3). First the major Sonogashira reaction product 15 was obtained from 14, along with some of the desilylated product 16. Compound 15 then furnished 1-alkynyl(naphthyl)iodonium tetrafluoroborate (17) and the triflate analogue 18 upon reaction with iodosylbenzene/ $\mathrm{NaBF}_{4}$ or the Zefirov reagent, 
respectively. We did not try to isolate and characterize all these iodonium salts (assumed to be reasonably stable) since they could be successfully employed in their reactions with benzenesulfinate without any further purification.

\section{Scheme 3.}

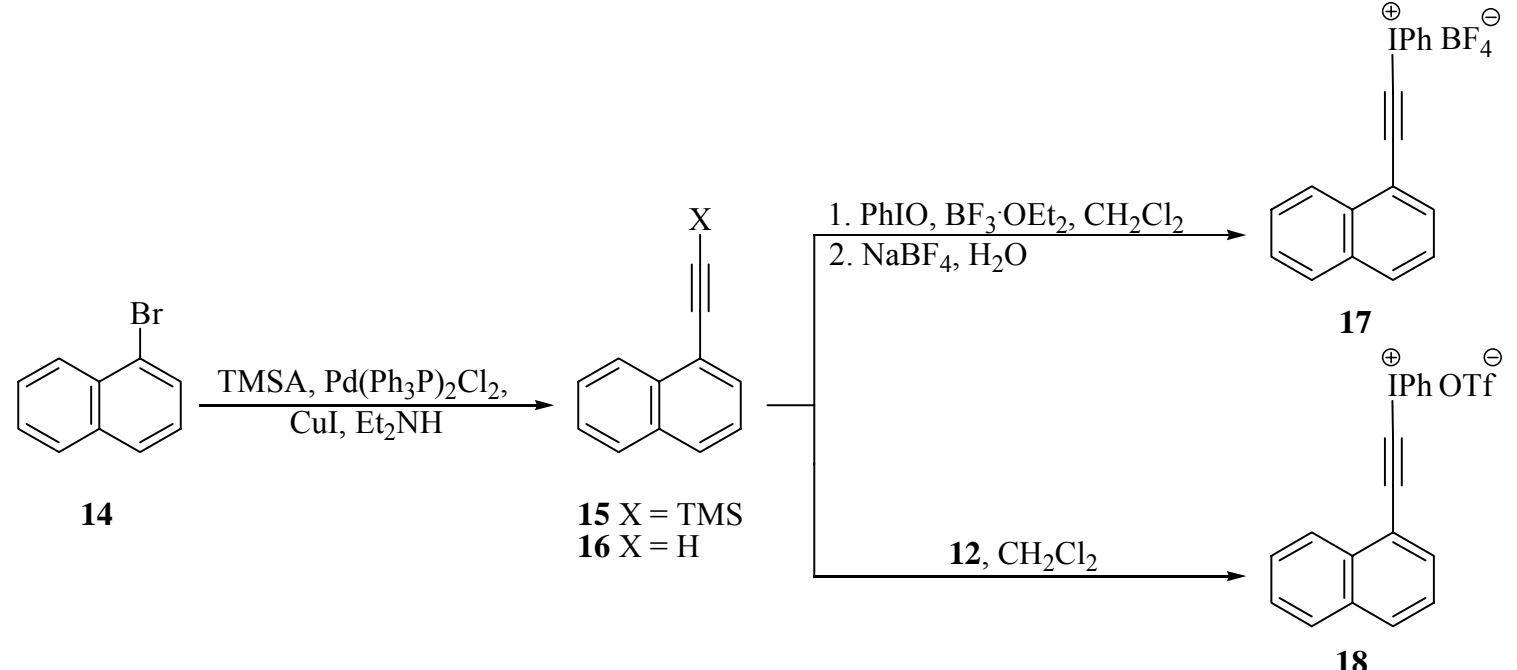

Tetrafluoroborate 11a reacted first with $\mathrm{PhSO}_{2} \mathrm{Na}$ according to the general scheme shown in Table 1 (see also Figure 1). This reaction (entry 1) furnished in moderate yield the indene derivatives 19a and 20a as an inseparable mixture, along with the rearrangement product, phenylsulfonylacetylene 21a. The observations that 19a and 20a could not be separated (although they have slightly different $R_{\mathrm{f}}$ values) and that they were always obtained in the same ratio (ca. 5:1) from several runs points to the existence of an equilibrium between them. Thus, indene 20a, initially formed from 23a through carbene insertion to the $\mathrm{C}-\mathrm{H}$ of methyl group, partially isomerized to the more stable 19a (Scheme 4). Indeed, addition of $\mathrm{Et}_{3} \mathrm{~N}$ to a solution of 19a and 20a in $\mathrm{CH}_{2} \mathrm{Cl}_{2}$ did not alter this equilibrium and only slow decomposition was observed after prolonged stirring (two weeks) at room temperature [31].

Next we explored the reactivity of $\mathbf{1 1 b}$ which, in contrast with 11a, yielded a single phenylsulfonyl indene derivative, 19b, accompanied again by the acetylene sulfone $\mathbf{2 1 \mathbf { b }}$ (entry 3 ). It is assumed that in this case the carbene insertion product 20b was irreversibly isomerized to 19b (Scheme 4). Generally, the sulfone group lacks the ability to participate in conjugation, therefore indenes 19, in which conjugation with the aromatic ring is possible, are favored. One would expect that, concerning 20b, the introduction of an extra methyl group, would lead to a less favorable 1,3- $\mathrm{H}$ shift system (in comparison with the 19a-20a pair). However, from the experimental results it becomes apparent that this is not the case. Due probably to steric factors, this shift is not reversible and once 20b is isomerized to 19b the indene system is locked. Another plausible explanation could be that alkene 19b is thermodynamically more stable since the conjugated double bond is trisubstituted.

The same reactions were also investigated employing the corresponding triflates 13a and 13b (entries 2 and 4, Table 1). Product distributions were similar to those obtained from tetrafluoroborates, but reaction mixtures were easier to resolve and the phenylsulfonylindenes were isolated in higher yields. Additionally, although not completely rationalized, annulation was slightly favored over rearrangement. 
Figure 1.<smiles>[R]C1=CC([SbH]([O])O)c2ccccc21</smiles>

$$
\begin{aligned}
\text { 19a } \mathrm{R} & =\mathrm{H} \\
\text { b } \mathrm{R} & =\mathrm{Me} \\
\text { c } \mathrm{R} & =\mathrm{OMe}
\end{aligned}
$$<smiles>[R]C1C=C(S)c2ccccc21</smiles>

20a $\mathrm{R}=\mathrm{H}$ b $\mathrm{R}=\mathrm{Me}$
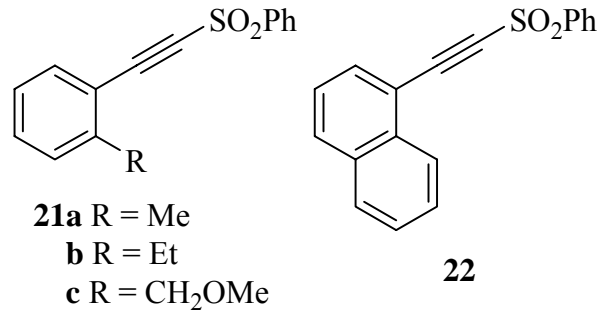

22

\begin{tabular}{|c|c|c|c|}
\hline Entry & Substrate & Ring type products (A) & Rearrangement type products $(\mathbf{B})$ \\
\hline 1 & 11a & $19 a+20 a(32 \%, 5: 1)^{a}$ & $21 a(26 \%)$ \\
\hline 2 & 13a & $19 a+20 a(44 \%, 5: 1)$ & $21 \mathrm{a}(26 \%)$ \\
\hline 3 & 11b & 19b $(40 \%)$ & $21 b(26 \%)$ \\
\hline 4 & $13 b$ & 19b $(51 \%)$ & $21 \mathbf{b}(20 \%)$ \\
\hline 5 & 11c & - & - \\
\hline 6 & $13 c$ & - & - \\
\hline 7 & 17 & - & $22(15 \%)$ \\
\hline 8 & 18 & - & $22(16 \%)$ \\
\hline
\end{tabular}

Table 1.

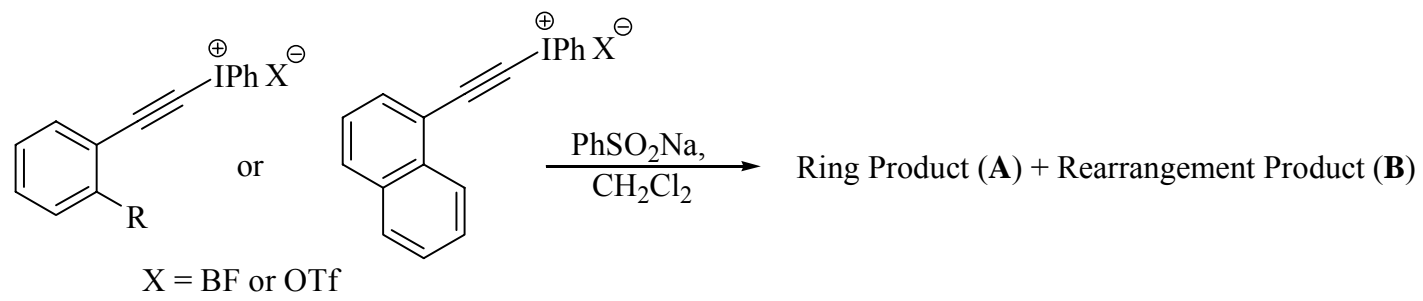

${ }^{a}$ All yields refer to isolated products (overall from the corresponding halides), unless otherwise mentioned. For details see the Experimental section.

We sought next to explore the reactivity of methoxy iodonium salts 11c and 13c (entries 5 and 6), but these substrates yielded very complex reaction mixtures with $\mathrm{PhSO}_{2} \mathrm{Na}$, which after chromatographic separations did not furnish any of the expected methoxy analogues 19c and 21c [32]. The situation was not improved when the reaction with the nucleophile was performed at lower temperatures. The different reactivity behavior of 11c and 13c might be due to an interaction of the ether oxygen with the initially formed carbene [33] and it is possible that in our case this kind of insertion does not lead to stable products. 


\section{Scheme 4.}

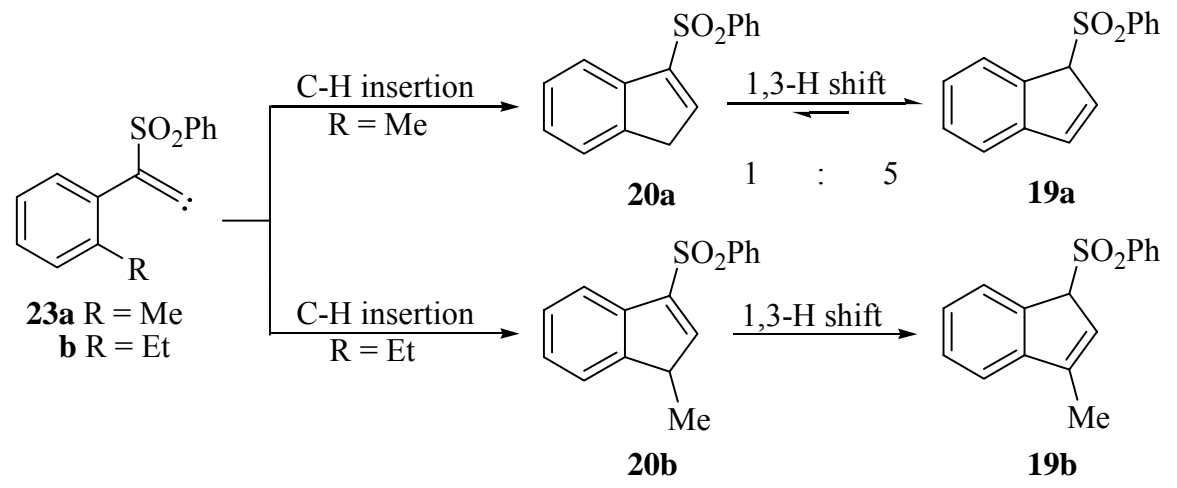

Carbene insertion to an aromatic C-H bond is another feasible reaction pathway [34-37], but none of the reactions with $\mathbf{1 1}$ and $\mathbf{1 3}$ we investigated produced such derivatives. In order to check this reactivity pattern phenylsulfinate addition to the naphthyl iodonium salts $\mathbf{1 7}$ and $\mathbf{1 8}$ was examined, since these substrates lack the possibility of insertion to an $\mathrm{sp}^{3} \mathrm{C}-\mathrm{H}$, but these derivatives gave only the rearrangement product 22 in low yield upon nucleophile addition (entries 7 and 8).

\section{Conclusions}

In this article we have presented an investigation of the reactivity patterns of some new alkynyl(phenyl)iodonium tetrafluoroborates and triflates upon addition of phenylsulfinate. The preparation of indene and phenylsulfonyl acetylene derivatives was accomplished in moderate to good yields depending on the exact reaction conditions and substrates involved. Further exploration of this kind of iodonium salts could lead to a general scheme for the synthesis of such systems.

\section{Acknowledgements}

We thank Prof. John K. Gallos for his suggestions and comments.

\section{Experimental}

\section{General}

All reagents are commercially available and were used without further purification unless otherwise mentioned. Solvents were dried by standard methods. The progress of the reactions was checked by thin layer chromatography (TLC) on Merck silica gel 60F254 glass plates $(0.25 \mathrm{~mm})$. Column chromatography was performed with Merck silica gel $60(0.063-0.200 \mathrm{~mm})$. The ${ }^{1} \mathrm{H}-$ and ${ }^{13} \mathrm{C}-\mathrm{NMR}$ spectra were recorded at 300 and $75 \mathrm{MHz}$, respectively, on a Bruker 300 AM spectrometer, with tetramethylsilane (TMS) as internal standard. High-resolution mass spectra (HRMS) were obtained on a VG ZAB-ZSE mass spectrometer under fast-atom bombardment (FAB) conditions with nitrobenzyl alcohol (NBA) as the matrix or on an IONSPEC FTMS spectrometer (matrix-assisted laser-desorption ionization, MALDI) with 2,5-dihydroxybenzoic acid (DHB) as matrix. 
General procedure for the preparation of 2-aryl-trimethylsilylacetylenes 9 and 15 [23-24]

Aryl halides 8 or $14(20 \mathrm{mmol})$ were dissolved in $\mathrm{Et}_{2} \mathrm{NH}(80 \mathrm{~mL})$ under an inert atomsphere. Trimethylsilylacetylene (TMSA, $2.36 \mathrm{~g}, 24 \mathrm{mmol}), \mathrm{Pd}\left(\mathrm{Ph}_{3}\right)_{2} \mathrm{Cl}_{2}(0.28 \mathrm{~g}, 0.4 \mathrm{mmol})$ and $\mathrm{CuI}(40 \mathrm{mg}$, $0.2 \mathrm{mmol}$ ) were then added successively and the mixture was left under vigorous stirring for $5 \mathrm{~h}$ at room temperature. The solvent was evaporated and hexane $(50 \mathrm{~mL})$ was added to the residue. After stirring for $1 \mathrm{~h}$ the supernatant solution was collected and concentrated to a volume of $c a$. $10 \mathrm{~mL}$. This was chromatographed on a silica gel column (hexane eluent) to afford 2-aryltrimethylsilylacetylenes 9 and $\mathbf{1 5}$ and the corresponding desilylated by-products $\mathbf{1 0}$ and $\mathbf{1 6}$ in this order.

Trimethyl(2-o-tolylethynyl)silane (9a). Obtained from 8a (3.42 g, 91\%). This compound had identical physical and spectra data with those reported in the literature [38].

1-Ethynyl-2-methylbenzene (10a). Obtained from 8a $(120 \mathrm{mg}, 5 \%) ;{ }^{1} \mathrm{H}-\mathrm{NMR}\left(\mathrm{CDCl}_{3}\right) \delta: 7.51(\mathrm{~d}, J=$ $7.9 \mathrm{~Hz}, 1 \mathrm{H}), 7.26-7.19(\mathrm{~m}, 2 \mathrm{H}), 7.16(\mathrm{t}, J=7.9 \mathrm{~Hz}, 1 \mathrm{H}), 2.53(\mathrm{~s}, 1 \mathrm{H}), 2.50(\mathrm{~s}, 3 \mathrm{H}) ;{ }^{13} \mathrm{C}-\mathrm{NMR}\left(\mathrm{CDCl}_{3}\right)$ $\delta: 140.1,132.7,131.4,129.8,125.0,121.7,81.8,81.4,18.2$; HRMS m/e Calc. for $\mathrm{C}_{9} \mathrm{H}_{9}\left[(\mathrm{M}+\mathrm{H})^{+}\right]$: 117.0704. Found: 117.0707.

[2-(2-ethylphenyl)ethynyl]trimethylsilane (9b). Obtained from $8 \mathbf{b}(3.65 \mathrm{~g}, 90 \%) ;{ }^{1} \mathrm{H}-\mathrm{NMR}\left(\mathrm{CDCl}_{3}\right)$ $\delta: 7.43(\mathrm{~d}, J=7.3 \mathrm{~Hz}, 1 \mathrm{H}), 7.25(\mathrm{~d}, J=4.3 \mathrm{~Hz}, 1 \mathrm{H}), 7.20(\mathrm{t}, J=6.1 \mathrm{~Hz}), 1 \mathrm{H}), 7.12(\mathrm{t}, J=7.3 \mathrm{~Hz}, 1 \mathrm{H})$, 2.81 (q, $J=7.3 \mathrm{~Hz}, 2 \mathrm{H}), 1.24$ (t, $J=7.3 \mathrm{~Hz}, 3 \mathrm{H}), 0.26(\mathrm{~s}, 9 \mathrm{H}) ;{ }^{13} \mathrm{C} \mathrm{NMR}\left(\mathrm{CDCl}_{3}\right) \delta: 146.7,132.4$, $128.7,127.9,125.5,122.2,103.9,97.7,27.7,14.6,-0.1$; HRMS m/e Calc. for $\mathrm{C}_{13} \mathrm{H}_{19} \mathrm{Si}\left[(\mathrm{M}+\mathrm{H})^{+}\right]$: 203.1256. Found: 203.1257.

1-Ethyl-2-ethynylbenzene (10b). Obtained from $8 \mathbf{b}(105 \mathrm{mg}, 4 \%) ;{ }^{1} \mathrm{H}-\mathrm{NMR}\left(\mathrm{CDCl}_{3}\right) \delta: 7.50(\mathrm{~d}, J=7.5$ $\mathrm{Hz}, 1 \mathrm{H}), 7.26-7.20(\mathrm{~m}, 2 \mathrm{H}), 7.12(\mathrm{t}, J=7.3 \mathrm{~Hz}, 1 \mathrm{H}), 2.89(\mathrm{~s}, 1 \mathrm{H}), 2.79$ (q, $J=7.3 \mathrm{~Hz}, 2 \mathrm{H}), 1.24(\mathrm{t}, J=$ $7.3 \mathrm{~Hz}, 3 \mathrm{H}) ;{ }^{13} \mathrm{C}-\mathrm{NMR}\left(\mathrm{CDCl}_{3}\right) \delta: 142.3,132.8,128.8,127.8,125.5,121.5,82.0,81.3,27.2,15.7$; HRMS m/e Calc. for $\mathrm{C}_{10} \mathrm{H}_{11}\left[(\mathrm{M}+\mathrm{H})^{+}\right]$: 131.0861. Found: 131.0879 .

[2-[2-(Methoxymethyl)phenyl]ethynyl]trimethylsilane (9c). Obtained from 8c $(4.17 \mathrm{~g}, 96 \%)$. This compound had been previously prepared following the same procedure [39].

1-Ethynyl-2-(methoxymethyl)benzene (10c). Obtained from 8c $(60 \mathrm{mg}, 2 \%)$. This compound had identical physical and spectra data identical with those reported in the literature [39].

Trimethyl[2-(naphthalen-5-yl)ethynyl]silane (15). Obtained from 14 (3.90 g, 87\%). This compound had been previously prepared using the corresponding iodide as starting material according to the same procedure [40]. ${ }^{1} \mathrm{H}-\mathrm{NMR}\left(\mathrm{CDCl}_{3}\right) \delta: 8.41(\mathrm{~d}, J=8.3 \mathrm{~Hz}, 1 \mathrm{H}), 7.87(\mathrm{~d}, J=7.0 \mathrm{~Hz}, 1 \mathrm{H}), 7.85(\mathrm{~d}, J=7.2$ $\mathrm{Hz}, 1 \mathrm{H}), 7.76(\mathrm{~d}, J=7.3 \mathrm{~Hz}, 1 \mathrm{H}), 7.63(\mathrm{t}, J=7.8 \mathrm{~Hz}, 1 \mathrm{H}), 7.55(\mathrm{t}, J=7.3 \mathrm{~Hz}, 1 \mathrm{H}), 7.44$ (t, $J=7.8 \mathrm{~Hz}$, $1 \mathrm{H}), 0.40(\mathrm{~s}, 9 \mathrm{H}) ;{ }^{13} \mathrm{C}-\mathrm{NMR}\left(\mathrm{CDCl}_{3}\right) \delta: 133.4,133.1,130.8,129.0,128.2,126.8,126.3,126.2,125.1$, $120.8,103.1,99.4,0.01$. 
1-Ethynylnaphthalene (16). Obtained from $14(150 \mathrm{mg}, 5 \%)$. This compound had physical and spectra data identical with those reported in the literature [41-42].

\section{General procedure for the preparation of tetrafluoroborates 11 and 17 [26-27]}

PhIO (3.52 g, $16 \mathrm{mmol})$ [25] and $\mathrm{BF}_{3} \cdot \mathrm{OEt}_{2}(2 \mathrm{~mL}, 16 \mathrm{mmol})$ were added to a solution of 2-aryltrimethylsilylacetylenes 9 or $15(10 \mathrm{mmol})$ in dry $\mathrm{CH}_{2} \mathrm{Cl}_{2}(40 \mathrm{~mL})$ and the mixture was stirred under an inert atmosphere at room temperature for $4 \mathrm{~h}$. Then a solution of $\mathrm{NaBF}_{4}(5.5 \mathrm{~g}, 50 \mathrm{mmol})$ in $\mathrm{H}_{2} \mathrm{O}(20$ $\mathrm{mL}$ ) was added and the resulting two phase system was vigorously stirred for 15 min at room temperature. The organic layer was collected, the aqueous one was extracted with $\mathrm{CH}_{2} \mathrm{Cl}_{2}(25 \mathrm{~mL})$ and the combined organic phases were dried over $\mathrm{MgSO}_{4}$. Filtration of the drying agent afforded a solution of crude tetrafluoroborates $\mathbf{1 1}$ and 17, which were used in the next step without further purification.

\section{General procedure for the preparation of triflates 13 and 18 [29-30]}

A solution of 2-aryltrimethylsilylacetylenes 9 or $\mathbf{1 5}(10 \mathrm{mmol})$ in dry $\mathrm{CH}_{2} \mathrm{Cl}_{2}(10 \mathrm{~mL})$ was added dropwise to a previously prepared solution of the Zefirov reagent $(\mathbf{1 2}, c a .7 \mathrm{mmol})$ in $\operatorname{dry~} \mathrm{CH}_{2} \mathrm{Cl}_{2}$ [28] at $0{ }^{\circ} \mathrm{C}$. The reaction mixture was allowed to stir for $1 \mathrm{~h}$ at the same temperature to provide a solution of crude triflates $\mathbf{1 3}$ and $\mathbf{1 8}$, which was used in the next step without further purification.

\section{General procedure for the nucleophilic addition of sodium benzenesulfinate to iodonium salts}

Sodium benzenesulfinate $(1.8 \mathrm{~g}, 11 \mathrm{mmol})$ was added to a solution of the above mentioned solutions of tetrafluoroborates or triflates $(c a .10 \mathrm{mmol})$ and the mixture was stirred under an inert atmosphere for $1 \mathrm{~h}$. Then $\mathrm{CH}_{2} \mathrm{Cl}_{2}(30 \mathrm{~mL})$ and $\mathrm{H}_{2} \mathrm{O}(20 \mathrm{~mL})$ were added and after extraction the organic phase was dried over $\mathrm{MgSO}_{4}$. Evaporation of the solvent yielded a residue which was purified by column chromatography (silica gel) using as eluent a 1/10 mixture of ethyl acetate and hexane.

1-(Phenylsulfonyl)-1H-indene (19a) and 3-(phenylsulfonyl)-1H-indene (20). Prepared from either 11a (820 mg, 32\% overall from 9a) or 13a (1.13 g, 44\% overall from 9a), these compounds were obtained as an inseparable mixture (ratio ca. 5:1). 19a: ${ }^{1} \mathrm{H}-\mathrm{NMR}\left(\mathrm{CDCl}_{3}\right) \delta: 7.91(\mathrm{bd}, J=7.5 \mathrm{~Hz}, 1 \mathrm{H}), 7.50$ $7.43(\mathrm{~m}, 3 \mathrm{H}), 7.31-7.23(\mathrm{~m}, 4 \mathrm{H}), 7.12(\mathrm{bd}, J=7.9 \mathrm{~Hz}, 1 \mathrm{H}), 6.77(\mathrm{~d}, J=5.5 \mathrm{~Hz}, 1 \mathrm{H}), 6.47$ (d, $J=5.5$ $\mathrm{Hz}, 1 \mathrm{H}), 5.07(\mathrm{~s}, 1 \mathrm{H}) ;{ }^{13} \mathrm{C}-\mathrm{NMR}\left(\mathrm{CDCl}_{3}\right) \delta: 144.3,143.4,137.4,135.5,133.5,129.1,129.0,127.9$, 127.8, 126.3, 125.7, 121.6, 73.5; HRMS (for the mixture) $\mathrm{m} / \mathrm{e}$ Calc. for $\mathrm{C}_{15} \mathrm{H}_{13} \mathrm{O}_{2} \mathrm{~S}\left[(\mathrm{M}+\mathrm{H})^{+}\right]$: 257.0636. Found: 257.0640. 20: ${ }^{1} \mathrm{H}-\mathrm{NMR}\left(\mathrm{CDCl}_{3}\right) \delta: 8.06(\mathrm{~d}, J=7.9 \mathrm{~Hz}, 2 \mathrm{H}), 7.73(\mathrm{~d}, J=7.3 \mathrm{~Hz}$, $1 \mathrm{H}), 7.63-7.43$ (m, 3H, partially obscured), 7.30-7.25 (m, 3H, obscured), 7.00 (bs, 1H), 3.61 (bs, 2H).

1-(2-o-Tolylethynylsulfonyl)benzene (21a). Prepared from either 11a (670 mg, 26\% overall from 9a) or 13a $\left(510 \mathrm{mg}, 20 \%\right.$ overall from 9a). ${ }^{1} \mathrm{H}-\mathrm{NMR}\left(\mathrm{CDCl}_{3}\right) \delta: 8.09(\mathrm{~d}, J=7.3 \mathrm{~Hz}, 2 \mathrm{H}), 7.70(\mathrm{t}, J=7.3 \mathrm{~Hz}$, $1 \mathrm{H}), 7.63(\mathrm{t}, J=8.0 \mathrm{~Hz}, 2 \mathrm{H}), 7.47(\mathrm{~d}, J=7.3 \mathrm{~Hz}, 1 \mathrm{H}), 7.36(\mathrm{t}, J=7.3 \mathrm{~Hz}, 1 \mathrm{H}), 7.22(\mathrm{~d}, J=8.0 \mathrm{~Hz}$, $1 \mathrm{H}), 7.18(\mathrm{t}, J=7.3 \mathrm{~Hz}, 1 \mathrm{H}) ;{ }^{13} \mathrm{C}-\mathrm{NMR}\left(\mathrm{CDCl}_{3}\right) \delta: 142.2,142.0,133.8,132.8,131.3,129.8,129.2$, 127.9, 127.1, 115.7, 93.1, 88.9, 20.2; HRMS m/e Calc. for $\mathrm{C}_{15} \mathrm{H}_{13} \mathrm{O}_{2} \mathrm{~S}\left[(\mathrm{M}+\mathrm{H})^{+}\right]: 257.0636$. Found: 257.0633 . 
3-Methyl-1-(phenylsulfonyl)-1H-indene (19b). Prepared from either 11b (1.08 g, 40\% overall from 15) or 13b (1.375 g, 51\% overall from 15). ${ }^{1} \mathrm{H}-\mathrm{NMR}\left(\mathrm{CDCl}_{3}\right) \delta: 7.83$ (bd, $\left.J=7.9 \mathrm{~Hz}, 1 \mathrm{H}\right), 7.46(\mathrm{~d}, J=7.9$ $\mathrm{Hz}, 2 \mathrm{H}), 7.43(\mathrm{t}, J=7.3 \mathrm{~Hz}, 1 \mathrm{H}), 7.33-7.28(\mathrm{~m}, 2 \mathrm{H}), 7.23$ (t, $J=7.9 \mathrm{~Hz}, 2 \mathrm{H}), 7.04$ (bd, $J=7.9 \mathrm{~Hz}$, 1H), 6.11 (bs, 1H), 4.97 (bs, 1H), $1.94(\mathrm{~s}, 3 \mathrm{H}) ;{ }^{13} \mathrm{C}-\mathrm{NMR}\left(\mathrm{CDCl}_{3}\right)$ 8: 146.4, 145.5, 135.9, 135.0, 133.3, 129.0, 128.8, 127.6, 126.1, 125.4, 122.4, 119.4, 72.3, 12.7; HRMS m/e Calc. for $\mathrm{C}_{16} \mathrm{H}_{15} \mathrm{O}_{2} \mathrm{~S}\left[(\mathrm{M}+\mathrm{H})^{+}\right]$: 271.0793. Found: 271.0797.

1-[2-(2-Ethylphenyl)ethynylsulfonyl]benzene (21b). Prepared from either 11b (760 mg, 26\% overall from 9b) or 13b (700 mg, 20\% overall from 9b); ${ }^{1} \mathrm{H}-\mathrm{NMR}\left(\mathrm{CDCl}_{3}\right) \delta: 8.09(\mathrm{~d}, J=8.1 \mathrm{~Hz}, 2 \mathrm{H}), 7.69(\mathrm{t}$, $J=7.1 \mathrm{~Hz}, 1 \mathrm{H}), 7.60(\mathrm{t}, J=6.8 \mathrm{~Hz}, 2 \mathrm{H}), 7.48(\mathrm{~d}, J=7.8 \mathrm{~Hz}, 1 \mathrm{H}), 7.39$ (t, $J=7.5 \mathrm{~Hz}, 1 \mathrm{H}), 7.26(\mathrm{bs}$, $1 \mathrm{H}), 7.19(\mathrm{t}, J=7.4 \mathrm{~Hz}, 1 \mathrm{H}), 2.69(\mathrm{q}, J=7.8 \mathrm{~Hz}, 2 \mathrm{H}), 1.38(\mathrm{t}, J=7.8 \mathrm{~Hz}, 3 \mathrm{H}) ;{ }^{13} \mathrm{C}-\mathrm{NMR}\left(\mathrm{CDCl}_{3}\right) \delta$ : $148.6,134.0,133.4,133.3,131.8,129.3,128.4,127.3,126.0,122.5,94.3,72.4,27.6,14.8 ; \mathrm{HRMS} \mathrm{m} / \mathrm{e}$ Calc. for $\mathrm{C}_{16} \mathrm{H}_{15} \mathrm{O}_{2} \mathrm{~S}\left[(\mathrm{M}+\mathrm{H})^{+}\right]$: 271.0793. Found: 270.0792 .

1-(2-(Phenylsulfonyl)ethynyl)naphthalene (22). Prepared from either 17 (440 mg, 15\% overall from 15) or 18 (465 mg, 16\% overall from 15); ${ }^{1} \mathrm{H}-\mathrm{NMR}\left(\mathrm{CDCl}_{3}\right) \delta: 8.77(\mathrm{~d}, J=8.2 \mathrm{~Hz}, 1 \mathrm{H}), 8.12(\mathrm{~d}, J=$ $7.0 \mathrm{~Hz}, 1 \mathrm{H}), 8.10(\mathrm{~d}, J=8.0 \mathrm{~Hz}, 2 \mathrm{H}), 8.00(\mathrm{~d}, J=7.1 \mathrm{~Hz}, 1 \mathrm{H}), 8.06(\mathrm{~d}, J=7.3 \mathrm{~Hz}, 1 \mathrm{H}), 7.81(\mathrm{t}, J=7.7$ $\mathrm{Hz}, 1 \mathrm{H}), 7.86(\mathrm{t}, J=7.3 \mathrm{~Hz}, 1 \mathrm{H}), 7.62(\mathrm{t}, J=7.5 \mathrm{~Hz}, 2 \mathrm{H}), 7.42$ (t, $J=7.7 \mathrm{~Hz}, 1 \mathrm{H}), 7.39$ (t, $J=7.3 \mathrm{~Hz}$, $1 \mathrm{H}) ;{ }^{13} \mathrm{C}-\mathrm{NMR}\left(\mathrm{CDCl}_{3}\right) \delta: 134.5,134.2,134.0,132.0,131.9,130.2,128.6,128.5,127.1,126.3,124.7$, 124.5, 124.1, 120.5, 98.3, 72.6; HRMS m/e Calc. for $\mathrm{C}_{18} \mathrm{H}_{13} \mathrm{O}_{2} \mathrm{~S}\left[(\mathrm{M}+\mathrm{H})^{+}\right]$: 293.0636. Found: 293.0633.

\section{References and Notes}

1. Varvoglis A. The Chemistry of Polycoordinated Iodine; VCH: New York, 1992; pp. 267-276.

2. Varvoglis A. Chemical Transformations Induced by Hypervalent Iodine Reagents. Tetrahedron 1997, 53, 1179-1255.

3. Kirmse, W. Alkenylidenes in Organic Synthesis. Angew. Chem. Int. Ed. 1997, 36, 1164-1170.

4. Moriarty, R. M.; Vaid, R. K. Carbon-Carbon Bond Formation Via Hypervalent Iodine Oxidations. Synthesis 1990, 431-447.

5. Stang, P. J. Alkynyl- and Alkenyl(phenyl)iodonium Compounds. Angew. Chem. Int. Ed. 1992, 31, 274-285.

6. Stang, P. J.; Zdhankin, V. V. Organic Polyvalent Iodine Compounds. Chem. Rev. 1996, 96, 11231178.

7. Ochiai, M.; Zdhankin, V. V. In Topics in Current Chemistry: Hypervalent Iodine Chemistry; Wirth, T. Ed.; Springer: Berlin, 2003; pp. 52-57 and 120-130.

8. Varvoglis, A. Hypervalent Iodine in Organic Synthesis; Academic Press: San Diego, 1997; pp. 167-174.

9. Zdhankin, V. V.; Stang, P. J. Alkynyliodonium Salts in Organic Synthesis. Tetrahedron 1998, 54, 10927-10966.

10. Marshall Beringer, F.; Galton S. A. Acetylenic and Ethylenic Iodonium Salts and Their Reactions with a Carbanion. J. Org. Chem. 1965, 30, 1930-1934. 
11. Koser, G. F.; Rebrovic, L.; Wettach, R. H. Functionalization of Alkenes and Alkynes with [Hydroxy(tosyloxy)iodo]benzene. Bis(tosyloxy)alkanes, Vinylaryliodonium Tosylates, and Alkynylaryliodonium Tosylates. J. Org. Chem. 1981, 46, 4324-4326.

12. Feldman K. S.; Perkins, A. L. 1,6-C-H Insertion of Alkylidenecarbenes in 1-Naphthol and 1Anthrol Derivatives. Tetrahedron Lett. 2001, 42, 6031-6033.

13. For a representative example, see: Tykwinski, R. R.; Whiteford, J. A.; Stang, P. J. Alkylidenecarbene Insertions into Aromatic C-H Bonds in Solution. J. Chem. Soc. Chem. Commun. 1993, 1800-1801.

14. For a representative example, see: Williamson, B. L.; Tykwinski, R. R.; Stang, P. J. A New Method for the Synthesis of Cyclopentenones via the Tandem Michael Addition-Carbene Insertion Reaction of $\beta$-Ketoethynyl(phenyl)iodonium Salts. J. Am. Chem. Soc. 1994, 116, 93-98.

15. For a representative example, see: Feldman, K. S.; Mareska, D. A. Alkynyliodonium Salts in Organic Synthesis. Preparation of Annelated Dihydropyrroles by Cascade Addition/Bicyclization of Dienyltosylamide Anions with Phenyl(propynyl)iodonium Triflate. J. Org. Chem. 1999, 64, 5650-5660.

16. For a representative example, see: Feldman, K. S.; Bruendl, M. M.; Schildknegt, K. Preparation of Five-Membered Nitrogen-Containing Heterocycles via [Three-Atom + Two-Atom] Combination of Tosylamide Anions with Phenyl(propyny1)iodonium Triflate. J. Org. Chem. 1995, 60, 77227723.

17. For a representative example, see: Wipf, P.; Venkatraman, S. A New Thiazole Synthesis by Cyclocondensation of Thioamides and Alkynyl(Aryl)Iodonium Reagents. J. Org. Chem. 1996, 61, 8004-8005.

18. For a representative example, see: Nikas, S.; Rodios, N.; Varvoglis, A. The Reaction of Trimethylsilylethynyl(phenyl)iodonium Triflate with Some Phenolates: Formation of Substitution and $\mathrm{sp}^{2} \mathrm{C}-\mathrm{H}$ Insertion Products. Molecules 2000, 5, 1182-1186.

19. Ochiai, M.; Kunishima, M.; Tani, S.; Nagao, Y. Generation of [ $\beta$-(Phenylsulfony1)alkylidene]carbenes from Hypervalent Alkenyl- and Alkynyliodonium Tetrafluoroborates and Synthesis of 1 -(Phenylsulfony1)cyclopentenes. J. Am. Chem. Soc. 1991, 113, 3135-3142.

20. Tykwinski, R. R.; Stang, P. J.; Perksy, N. E. Preparation of Bis-Cyclopentene Ring Systems via Reaction of Bis[phenyl(iodonium)] Diyne Triflates with Soft Nucleophiles. Tetrahedron Lett. 1994, 35, 23-26.

21. Iodides $\mathbf{8 a}$ and $\mathbf{8 b}$ are commercially available.

22. Iodide 8c was prepared according to: Larock, R. C.; Harisson, L. W. Mercury in Organic Chemistry. 26. Synthesis of Heterocycles via Intramolecular Solvomercuration of Aryl Acetylenes. J. Am. Chem. Soc. 1984, 106, 4218-4227.

23. Takahashi, S.; Kuroyama, Y.; Sonogashira, K.; Hagihara, N. A Convenient Synthesis of Ethynylarenes and Di-ethynylarenes. Synthesis 1980, 627-631.

24. Sonogashira, K.; Tohda, Y.; Hagihara, N. A Convenient Synthesis of Acetylenes: Catalytic Substitutions of Acetylenic Hydrogen with Bromoalkenes, Iodoarenes, and Bromopyridines. Tetrahedron Lett. 1975, 4467-4470.

25. Saltzmann, H.; Sharefkin, J. G. Iodosobenzene. Organic Syntheses, 1973, Coll. Vol. V, 658-659. 
26. Ochiai, M.; Kunishima, M.; Sumi, K.; Nagao, Y.; Fujita, E.; Arimoto, M.; Yamaguchi, H. Reaction of Alkynyltrimethylsilanes with a Hypervalent Organoiodine Compound: A New General Synthesis of Alkynyliodonium Salts. Tetrahedron Lett. 1985, 26, 4501-4504.

27. Ochiai, M.; Ito, T.; Takaoka, Y.; Masaki, Y.; Kunishima, M.; Tani, S.; Nagao, Y. Synthesis of Ethynyl(phenyl)iodonium Tetrafluoroborate. A New Reagent for Ethynylation of 1,3-Dicarbonyl Compounds. J. Chem. Soc. Chem. Commun. 1990, 118-119.

28. Hembre, R. T.; Scott, C. P.; Norton, J. R. Conversion of Olefins to Ditriflates by $\mu$ Oxobis[(trifluoromethanesulfonato) (phenyl)iodine]. J. Org. Chem. 1987, 52, 3650-3654.

29. Bachi, M. D.; Bar-Ner, N.; Crittell, C. M.; Stang, P. J.; Williamson, B. L. Synthesis of Alkynyl(phenyl)iodonium Triflates and Their Reaction with Diethyl-2-Aminomalonate. J. Org. Chem. 1991, 58, 3912-3915.

30. Stang, P. J.; Arif, A. M.; Crittell, C. M. Ethynyl(phenyl)iodonium Triflate, $[\mathrm{HC} \equiv \mathrm{CIPh}]\left[\mathrm{OSO}_{2} \mathrm{CF}_{3}\right]$ : Preparation, Spectral Properties, Mechanism of Formation and X-ray Molecular Structure, Angew. Chem. Int. Ed. 1990, 29, 287-288.

31. The structures of 19a and 20a were proved unambiguously from the ${ }^{1} \mathrm{H}-\mathrm{NMR}$ spectra of their mixture. Thus, 19a has a peak at $\delta 5.07$ which integrates for one $\mathrm{H}$, whereas 20a gives a peak at $\delta$ 3.61 which integrates for two $\mathrm{H}$. Similar conclusions were reached from their ${ }^{13} \mathrm{C}$-NMR spectra.

32. ${ }^{1} \mathrm{H}-\mathrm{NMR}$ of the crude trifluroborate or triflate revealed that these salts were indeed formed.

33. Feldman, K. S.; Wrobleski, M. L. Alkynyliodonium Salts in Organic Synthesis. Preparation of 2Substituted-3-p-toluenesulfonyldihydrofurans from 1-Hydroxybut-3-ynyliodonium Ethers via a Formal Stevens Shift of a Carbon Group. Org. Lett. 2000, 2, 2603-2605.

34. See refs. [13], [16] and [18].

35. Kitamura, T.; Zheng, L.; Taniguchi, H.; Sakurai, M.; Tanaka, R. Novel Cyclization to Benzofurans in the Reaction of Alkynyl( $p$-phenylene)bisiodonium Ditriflates with Phenoxide Anion. Tetrahedron Lett. 1993, 34, 4055-4058.

36. Kitamura, T.; Zheng, L.; Fukuoka, T.; Fujiwara, Y.; Taniguchi, H.; Sakurai, M.; Tanaka, R. Aromatic $\mathrm{C}-\mathrm{H}$ Insertion of $\beta$-Phenoxyalkylidenecarbenes Generated by Reaction of Alkynyl( $p$ phenylene)bisiodonium Ditrifluoromethanosulfonates (Ditriflates) with Phenoxide Anions. $J$. Chem. Soc. Perkin Trans. 2 1997, 1511-1515.

37. Kitamura, T.; Tsuda, K.; Fujiwara, Y. Novel Heteroaromatic C-H Insertion of Alkylidenecarbenes. A New Entry to Furopyridine Synthesis. Tetrahedron Lett. 1998, 39, 53755376.

38 D'Auria, M. Naturally Occurring 5-[(2-Thienyl)(ethynyl)]thiophene-2-carbaldehyde through a Short Synthesis of Diarylacetylenes. Synth. Commun. 1992, 22, 2393-2399.

39. Li, H.; Yang, H.; Petersen, J. L.; Wang, K. K. Biradicals/Zwitterions from Thermolysis of EnyneIsocyanates. Application to the Synthesis of 2(1H)-Pyridones, Benzofuro[3,2-c]pyridin-1(2H)ones, 2,5-Dihydro-1H-pyrido[4,3-b]indol-1-ones, and Related Compounds. J. Org. Chem. 2004, 69, 4500-4508.

40. Butler, I. R.; Soucy-Breau, C. Bipyridylacetylenes 1: The Synthesis of Some Bipyridylacetylenes via the Palladium-catalyzed Coupling of Acetylenes with 2,2'-Dibromobipyridyl, and the Single Crystal X-ray Structure of 6,6'-Biphenylethynyl-2,2'-bipyridine, Can. J. Chem. 1991, 69, 11171123. 
41. Yoshiyuki, O.; Chellappa, K. L.; Kundu, S. K. Magnetic Shielding of Acetylenic Protons in Ethynylarenes. J. Org. Chem. 1972, 37, 3185-3187.

42. Card, P. J.; Friendli, F. E.; Shecheter H. Synthesis and Chemistry of 1H-Cyclobuta[de]naphthalenes, 1-Alkylidene-1H-cyclobuta[de]naphthalenes, and $1 H$-Cyclobuta[de $]$ naphthalen-1-one. J. Am. Chem. Soc. 1983, 105, 6104-6114.

Sample availability: Contact the authors.

(C) 2005 by MDPI (http:www.mdpi.org). Reproduction is permitted for noncommercial purposes. 